\title{
METHOD FOR EVALUATING INHOMOGENEOUS ALTERNATIVES WITH THE HIERARCHICAL STRUCTURE OF UNRELATED CRITERIA BASED ON MEDIUM-CONSISTENT MATRIX OF PAIR COMPARISONS
}

\author{
A. V. Melnikov ${ }^{1}$, meln78@mail.ru, \\ I. R. Narushev ${ }^{1}$, nar_i@bk.ru, \\ I. A. Kubasov ${ }^{2}$, igorak $\bar{k} @$ list.ru \\ ${ }^{1}$ Voronezh Institute of the Ministry of the Interior of Russia, Voronezh, Russian \\ Federation \\ 2 Academy of Management of the Ministry of the Interior of Russia, Moscow, Russian \\ Federation
}

\begin{abstract}
This article discusses inhomogeneous alternatives with unrelated criteria with a clusterhierarchical structure. The heterogeneity of alternatives is characterized by differences in the structure and number of criteria used in the process of obtaining an integral indicator. In order to construct an integral indicator, we form a block matrix of pairwise comparisons, the elements of which are taken from separate matrices of pairwise comparisons obtained by experts in the course of previous studies. In order to construct the missing elements of the block matrix, we formulate a rule describing the construction of medium-matched matrices of pairwise comparisons due to which the missing elements of the block matrix are calculated without the involvement of experts. This method allows to construct more than $60 \%$ of elements of the new block matrix, and takes into account the inconsistency in the paired comparisons made by experts. Also, this method allows to calculate the weight coefficients for a generalized integral indicator formed from individual elements of the matrix of pairwise comparisons obtained during the previous study, which saves costs arising during preliminary examination. In order to solve this problem, we use a clusterhierarchical approach, as well as methods of decomposition and synthesis. The results of the paper can be applied in problems of the theory of decision making, in the class of problems of integral estimation of multicriteria objects, and in problems with weak formalization.

Keywords: multi-criteria analysis; cluster-hierarchical approach; decision making; nonuniform alternatives; integral indicator; inconsistent estimates.
\end{abstract}

\section{Introduction}

Expert assessments, collective choice and other problems belong to the class of poorly formalized ones. Unlike fully formalized problems, where clear rules and conditions are formulated, poorly formalized problems require constant refinement, modification for a certain class of problems, and consideration of the human factor (for example, in expert systems) [1, 8]. Statement of the classical problems considered in the framework of the theory of decision making includes the following: ranking alternatives, clustering (assigning alternatives to a particular class), and finding the best alternative. Each of these classes of problems is considered under the following two conditions. First, the alternatives are fully defined at the time of the examination. Second, the alternatives are known only partially. 
In the framework of the integrated assessment of deviant behavior, there is the problem to obtain an integral estimate of $J$, which, if necessary, allows to compare visually the level of deviating behavior between alternatives $J_{i}[5,6]$. Deviant behavior is a complex phenomenon characterized and described by a multitude of classifications, has many manifestations, and requires different considerations within a certain approach [4, 7].

Classical methods of multi-criteria decision-making, including those based on the cluster-hierarchical approach, do not involve the synthesis of new indicators using different hierarchical levels $[9,10]$. Consider the following example. As a part of a study assessing deviant behavior, an enormous array of signs were selected to construct an integral indicator. Then, the signs were combined into structures, and experts made a pair-wise comparison of all criteria in order to obtain weights of signs. In the course of a new study, sometimes it is necessary to form a generalized indicator consisting of individual criteria that belong to different clusters and levels of hierarchy. Namely, such an indicator can be a matrix of pairwise comparisons obtained during the previous examination [2, 3]. In general, in order to evaluate non-dominated alternatives, a decomposition problem is necessary to select group matrices during the analysis and processing of information and the further synthesis of individual integral indicators based on previously obtained pairwise comparison matrices.

Having a perfectly matched matrix, it is enough to multiply the weight coefficient vector by the group indicator. However, in practice, the ratio of criteria among themselves is often not the same for all pairwise comparisons. In the limiting case, this leads to an inconsistency of the matrix of pairwise comparisons. Nevertheless, in this case, we have precisely pairwise comparisons that contain essential information that must be taken into account in order to improve the accuracy of estimation of the parameters under study.

The proposed method allows to eliminate the time-consuming examination procedures associated with the initial expert information gathering and processing.

Let us turn to the solution of the problem on developing a method for forming an integral index on the basis of the hierarchical structure of the space of signs of heterogeneous alternatives.

\section{Formation of Group Matrix of Support Elements}

\subsection{Construction of Matrix of Pairwise Comparisons of Support Elements}

The group matrix $D[f ; f]$ reflects the significance of the weighting factors between the support elements (having the maximum value in each of the groups). Here $f$ is the number of supporting elements in each matrix of pairwise comparisons used to synthesize the block matrix, $i$ is the ordinal number of the row, $i=1 \ldots f$, and $j$ is the ordinal number of the column, $j=1 \ldots k$.

$$
\begin{gathered}
D N[f ; f]=\left(\begin{array}{ccc}
1 & 5 & 9 \\
\cdots & 1 & 2 \\
\cdots & \cdots & 1
\end{array}\right) \\
D N[f ; f]=\left(\begin{array}{ccc}
D_{11} & D_{12} & D_{13} \\
\cdots & D_{22} & D_{23} \\
\cdots & \cdots & D_{33}
\end{array}\right)
\end{gathered}
$$




\subsection{Formation of Medium Consistent Ratio of Supporting Elements}

For the matrix $D[f ; f]$, we form the medium-consistent matrix $D N[1 ; f]$, taking into account the average-consistent relationship between the elements, where

$$
\begin{aligned}
& D N_{i j}=D N_{i j-1} * \widetilde{D N}_{i j}, \\
& \widetilde{D N}_{I J}=\frac{\sum_{k=i}^{f=j}\left(\frac{D_{k j}}{D_{k j-1}}\right)}{j-i} .
\end{aligned}
$$

Let us present the matrix element $D N[1 ; f]$ in the general form

$$
D N_{I J}=D N_{i j-1}\left(\frac{\sum_{k=i}^{f=j}\left(\frac{D_{k j}}{D_{k j-1}}\right)}{j-i}\right) \text {. }
$$

For the elements $D_{11}$ and $D_{12}$ of the matrix $D[f ; f]$, the elements $D_{i+1} j-1$ are below of the main diagonal. This means absolute consistency of these elements, because the relationship between them is unequivocal. Calculate the average consistent coefficient $\widetilde{D N}_{13}$ for the element $D_{11}$ of the matrix $D N[1 ; f]$ and obtain

$$
\widetilde{D N}_{13}=\frac{\frac{D_{13}}{D_{12}}+\frac{D_{23}}{D_{22}}}{2(r-j)}=\frac{19}{10} \text {. }
$$

$\widetilde{D N}_{13}$ is the medium consistent ratio between the third and the second elements of the matrix $D[f ; f]$ is

$$
\begin{gathered}
D N[1 ; f]=\left(\begin{array}{ccc}
1 & 5 & 19 / 2
\end{array}\right) \\
D N[1 ; f]=\left(\begin{array}{ccc}
D_{11} & D_{12} & D_{11} * \widetilde{D N}_{13}
\end{array}\right) .
\end{gathered}
$$

\section{Preparation of Block Structures to Construct Blood Matrix}

\subsection{Criteria Selection}

Consider pairwise comparison matrices $A \xi$, where $\xi$ is a matrix serial number $\xi \in$ $1 \ldots f$ whose elements are necessary to form a new integral indicator $A 1[r ; r]$

$$
A 1=\left(\begin{array}{cccc}
1 & 2 & 3 & 6 \\
\cdots & 1 & 2 & 3 \\
\cdots & \ldots & 1 & 2 \\
\cdots & \ldots & \ldots & 1
\end{array}\right)
$$

\subsection{Formation of Moderately Consistent Ratio of Matrix Elements}

For the matrix $A 1[r ; r]$, we form the average-consistent relation between the elements $A N \xi$ written in the form of the matrix $A N 1[1 ; r]$, where $A N 1_{i j}=A N 1_{i j-1} * \widetilde{A N}_{I J}$, 


$$
\begin{gathered}
\widetilde{A 1}_{I J}=\frac{\sum_{k=i}^{r=j} \frac{A 1_{k j}}{A 1_{k j-1}}}{j-i}, \\
A N 1_{i j}=A 1_{i j-1}\left(\frac{\sum_{k=i}^{f=j}\left(\frac{A 1_{k j}}{A 1_{k j-1}}\right)}{j-i}\right) .
\end{gathered}
$$

For the element $A 1_{13}$, we obtain the correction factor

$$
\widetilde{A 1}_{13}=\frac{\frac{A 1_{13}}{A 1_{12}}+\frac{A 1_{23}}{A 1_{22}}}{j-i}=\frac{7}{4}
$$

For the element $A N 1_{13}$ of the matrix $A N 1[1 ; r]$, we have that

$$
A N 1_{13}=A N 1_{12} \times \widetilde{A 1}_{I J} .
$$

By analogy, calculate the correction factor $\widetilde{A 1}_{14}$. Obtain the element $A N 1_{14}$ and write the matrix in the general form:

$$
A N 1=\left(\begin{array}{llll}
1 & 2 & 7 / 2 & 77 / 12
\end{array}\right)
$$

\subsection{Truncation of Matrices According to Elements}

Let us rewrite the matrix based on the second and the fourth elements, which are used later to construct the synthetic matrix

$$
A N 1=\left(\begin{array}{ll}
2 & 77 / 12
\end{array}\right) .
$$

In the synthetic generalized matrix, we write the necessary the second and the fourth elements keeping the initial ratios previously set by the experts.

$$
A_{1}=\left(\begin{array}{cc}
1 & 3 \\
1 \backslash 3 & 1
\end{array}\right)
$$

Similarly, consider matrices $A 2$ and $A 3$.

For the matrix $A 2[m ; m]$, we need to use the first, the second, and the fourth elements

$$
A 2=\left(\begin{array}{cccc}
1 & 1 & 3 & 4 \\
\ldots & 1 & 2 & 3 \\
\ldots & \ldots & 1 & 2 \\
\ldots & \ldots & \ldots & 1
\end{array}\right) .
$$

For the matrix $A 2[m ; m]$, we form the average consistent relation between the elements written in the form of the matrix $A N 2[1 ; m]$ :

$$
A N 2=\left(\begin{array}{llll}
1 & 1 & 5 / 2 & 145 / 36
\end{array}\right) .
$$

Let us rewrite the matrix based on the second and the fourth elements, which are used later to construct the synthetic matrix

$$
A N 2=\left(\begin{array}{lll}
1 & 1 & 145 / 36
\end{array}\right)
$$


In the block-generalized matrix, we write the matrix containing the first, the second, and the fourth elements while maintaining the original ratios previously set by experts.

$$
A_{2}=\left(\begin{array}{ccc}
1 & 1 & 4 \\
\ldots & 1 & 3 \\
\ldots & \ldots & 1
\end{array}\right)
$$

For the matrix $A 3[p ; p]$, it is necessary to use only the second element.

$$
A 3=\left(\begin{array}{ccc}
1 & 2 & 4 \\
\ldots & 1 & 2 \\
\ldots & \ldots & 1
\end{array}\right)
$$

For the matrix $A 3[p ; p]$, we form the average consistent relation between the elements written in the form of the matrix $A N 3[1 ; p]$ :

$$
A N 3=\left(\begin{array}{lll}
1 & 2 & 4
\end{array}\right)
$$

Let us rewrite the matrix based on the second and the fourth elements, which are used later to construct the block matrix

$$
A N 3=(2) .
$$

In the synthetic generalized matrix we write the only necessary element

$$
A_{3}=(1)
$$

\section{Construction of Block Matrix}

Construct a block matrix of pairwise comparisons $A[\gamma ; \gamma]$, where $\gamma=r+m+p$, for matrices of pairwise comparisons of dimension $[r ; r][m ; m][p ; p]$ containing matrices $A \xi$, which are truncated matrices of pairwise comparisons of dimension l as $[r ; r][m ; m][p ; p]$, etc., namely A1, A2, A3.

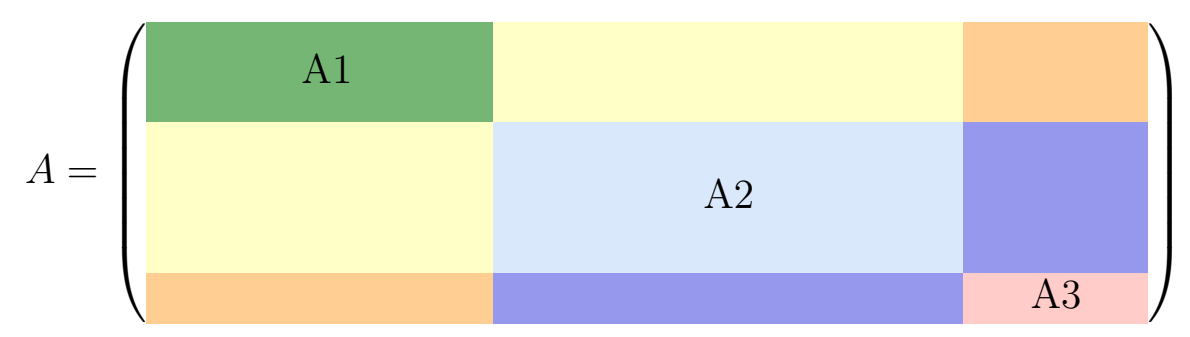

Let us write in general the rule for constructing the matrix: the value of the element of the matrix $A_{i j}$ is directly proportional to the significance in the reduced average-matched ratio within the group of the element of lesser significance $A N \xi_{j_{t}}$, the significance of the supporting element (group) of lesser importance $D N_{\xi_{g}}$, the ratio of compared elements of lesser significance to greater significance $\frac{A_{j j}}{A_{i i}}$, and inversely proportional to significance in the reduced average-matched ratio within the group of the element of greater significance $A N_{i_{y}}$, the significance of the supporting element (group) of greater importance in the reduced average-matched ratio of the supporting elements $D N_{\xi_{h}}$. 
We calculate the missing elements of the matrix according to the following formula:

$$
A_{i j}=\frac{A_{j j} * A N \xi_{j_{t}} * D N_{\xi_{g}}}{A_{i i} * A N \xi_{i_{y}} * D N_{\xi_{h}}},
$$

where $g$ is the $\xi$ group of an element of lesser significance than $\xi$ of the object group being compared,

$h$ is $\xi$ of the group of an element with greater significance than $\xi$ of the compared group of an object,

$t$ is the ordinal number of the element in the medium-consistent matrix $\xi$ defined by the rule $t=y-\sum l$, where $l \in \xi<\xi_{h}$,

$y$ is the ordinal number of the element in the medium-consistent matrix $\xi$ defined by the rule $y=y-\sum l$, where $l \in \xi<\xi_{g}$.

In particular, consider calculation of the element

$$
A_{23}=\frac{A_{11} D N_{12} A N 2_{11}}{A_{22} D N_{11} A N 1_{12}}
$$

Therefore, we have that

$$
A=\left(\begin{array}{cccccc}
1 & 3 & 5 / 2 & 5 / 2 & 725 / 72 & 38 \\
1 / 3 & 1 & 60 / 77 & 60 / 77 & 725 / 231 & 38 / 7 \\
2 / 5 & 77 / 60 & 1 & 1 & 4 & 19 / 5 \\
2 / 5 & 77 / 60 & 1 & 1 & 3 & 19 / 5 \\
72 / 725 & 231 / 725 & 1 / 4 & 1 / 3 & 1 & 684 / 725 \\
1 / 38 & 7 / 38 & 5 / 19 & 5 / 19 & 725 / 684 & 1
\end{array}\right) .
$$

\section{Research Result}

Let $W$ be the matrix of values, $\omega_{i i}$ be a pairwise comparisons, $\lambda_{\max }$ be the largest eigenvalue. In order to find approximately the vector of priorities, we need to find a vector $V$ that satisfies the equation

$$
W V=\lambda_{\max } V
$$

The consistency index is presented in the form, where $m$ is the number of criteria and is considered as an indicator of "proximity to consistency". In general, if $m \leq 0.1$, then we can be satisfied with the judgments.

$$
C I=\frac{\left(\lambda_{\max }-m\right)}{(m-1)}
$$

On the basis of the $C I$ consistency index, the $C R$ consistency ratio is computed as follows: $C R=C I / S S$, where $S S$ is the consistency value of a random matrix of the same order.

In order to define the eigenvectors of the matrix $A$, we use the built-in function "eigenvecs (A)"of Mathcad-14.

$$
V_{\text {gen }}=\left(\begin{array}{llllll}
0,897 & 0,231 & 0,265 & 0,254 & 0,069 & 0,053
\end{array}\right)
$$


We use the normalization of elements obtained from the eigenvector by dividing by the sum of its elements.

$$
\sum V_{i, g e n}=1.769
$$

$\widehat{V}=\frac{V_{i}}{\sum_{j=1}^{m} V_{i}}$ provides a comfortable ratio $\sum V_{i}=1$.

After normalization by dividing by this sum of attributes, we obtain the vector of priorities in the following form:

$$
\tilde{V}_{\text {gen }}^{\prime}=\left(\begin{array}{llllll}
0,507 & 0,13 & 0,15 & 0,144 & 0,039 & 0,03
\end{array}\right) .
$$

\section{Generalized Indicator}

For the purposes of this section, we choose scalar product as a generalized indicator of the quality of expertise.

$$
J=\langle V, x\rangle=\sum_{j=1}^{m} V_{i} x_{i}
$$

\section{Conclusion}

During the work, we consider an example of evaluating inhomogeneous alternatives with a cluster-hierarchical structure of unrelated criteria. In order to construct the integral indicator, we form a block matrix of pairwise comparisons, the elements of which are taken from separate matrices of pairwise comparisons obtained by experts in the course of previous studies. For the missing elements of the block matrix, we formulate a rule describing the construction of medium-matched matrices that allows to construct more than $60 \%$ of the elements of a new block matrix to take into account inconsistencies in the pairwise comparisons made by experts. The proposed method eliminates the timeconsuming examination procedures associated with the initial expert information gathering and processing.

\section{References}

1. Bahurmoz A.M., Mukhtar S.-M., Al-Sharqi L.M. AHP as an Effective ConsensusBased Selection Tool. Journal for Global Business Advancement, 2015, vol. 8, no. 2, pp. 138-156. DOI: 10.1504/JGBA.2015.069527.

2. Morewedge C.K., Giblin C.E. Explanations of the Endowment Effect: an Integrative Review. Trends in Cognitive Science, 2015, vol. 19, no. 6, pp. 339-348. DOI: $10.1016 /$ j.tics.2015.04.004.

3. Paxton A., Griffiths T.L. Finding the Traces of Behavioral and Cognitive Processes in the Data and of Course Occurring Datasets. Behavior Research Methods, 2017, vol. 49, no. 5, pp. 1630-1638. DOI: 10.3758/s13428-017-0874-x.

4. Kubasov I.A., Melnikov A.V., Maltsev S.A., Narushev I.R. Clustering of Objects with Poorly Formalized Features Based on a Neural Network in the Form 
of a Kohonen Layer. [Bulletin of VSUIT], 2018, vol. 80, no. 3, pp. 86-91. (in Russian) DOI: $10.20914 / 2310-1202-2018-3-86-91$.

5. Narushev I.R., Melnikov A.V., Denisenko V.V. Models of a Generalized Indicator of Deviant Behavior of Minors. Bulletin of the Voronezh Institute of the Ministry of Internal Affairs of Russia, 2018, no. 1, pp. 44-50. (in Russian).

6. Melnikov A.V., Narushev I.R. Generalized Indicator of Deviant Behavior of Minors. [Intellectual Information Systems], Proceedings of the All-Russian Conference with International Participation. WITH, 2017, pp. 185-188. (in Russian).

7. Narushev I.R., Maltsev S.A., Kubasov I.A. The Numerical Method of Matching the Object Base of the Examination of the Deviant Behavior of Minors Using the Hierarchy Analysis Method. Bulletin of the Voronezh Institute of the Federal Penitentiary Service of Russia, 2018, no. 4, pp. 89-97. (in Russian).

8. Saaty T. [Decision Making. Hierarchy Analysis Method]. Moscow, Radio and Communication, 1993. (in Russian).

9. Saaty T., Kerns K. [Analytical Planning. Organization of Systems]. Moscow, Radio and communication, 1991. (in Russian).

10. Saaty T. [Decision Making with Dependencies and Feedbacks: Analytical Networks]. Moscow, Publishing House LKI, 2008. (in Russian).

Alexander V. Melnikov, DSc (Math), Full Professor, Department of Mathematics and Systems Modeling, Voronezh Institute of the Ministry of the Interior of Russia (Voronezh, Russian Federation), meln78@mail.ru.

Ilya R. Narushev, Graduate student, Department of Mathematics and System Modeling, Voronezh Institute of the Ministry of the Interior of Russia, (Voronezh, Russian Federation),nar_i@bk.ru.

Igor A. Kubasov, DSc (Math), Full Professor, Department of Information Technologies, Academy of Management of the Ministry of the Interior of Russia, (Moscow, Russian Federation), igorak@list.ru.

Received June 7, 2019. 


\title{
МЕТОД ОЦЕНКИ НЕОДНОРОДНЫХ АЛЬТЕРНАТИВ С ИЕРАРХИЧЕСКОЙ СТРУКТУРОЙ НЕВЗАИМОСВЯЗАННЫХ КРИТЕРИЕВ НА ОСНОВЕ СРЕДНЕСОГЛАСОВАННЫХ МАТРИЦ ПАРНЫХ СРАВНЕНИЙ
}

\author{
А. В. Мелъников, И. Р. Нарушев, И. А. Кубасов
}

\begin{abstract}
В статье рассматриваются неоднородные альтернативы невзаимосвязанных критериев, обладающих кластерно-иерархической структурой. Неоднородность альтернатив характеризуется отличиями в структуре и количестве используемых критериев в ходе получения интегрального показателя. Для построения интегрального показателя формируется блочная матрица парных сравнений, элементы которых взяты из отдельных матриц парных сравнений, полученных экспертами в ходе ранее проведенных исследований. Для построения блочной матрицы сформировано правило, описывающее построение среднесогласованных матриц парных сравнений, благодаря которому рассчитываются недостающие элементы блочной матрицы без привлечения экспертов. Этот метод позволяет производить построение более $60 \%$ элементов новой блочной матрицы и учитывает несогласованность при парных сравнениях производимыми экспертами. При использовании описанного метода становится возможным вычисление весовых коэффициентов для обобщенного интегрального показателя, формирующегося из отдельных элементов матриц парных сравнений, полученных в ходе предыдущего исследования, что позволяет экономить затраты на этапе предварительной экспертизы. Для решения данной проблемы используется кластерно-иерархический подход, методы декомпозиции и синтеза. Результаты работы могут быть применены в задачах теории принятия решений, в классе задач интегрального оценивания многокритериальных объектах при рассмотрении задач со слабой формализцией.

Ключевые слова: многокритериальный анализ; кластерно-иерархический подход; принятие решений; неоднородные альтернативы; интегральный показатель; несогласованные оценки.
\end{abstract}

\section{Литература}

1. Bahurmoz, A.M. AHP as an Effective Consensus-Based Selection Tool: a Case of Personnel Selection for the Ministry of Foreign Affairs in Saudi Arabia / A.M. Bahurmoz, S.-M. Mukhtar, L.M. Al-Sharqi // Journal for Global Business Advancement. - 2015 - V. 8, № 2. - P. 138-156.

2. Morewedge, C.K. Explanations of the Endowment Effect: an Integrative Review C.K. Morewedge, C.E. Giblin // Trends in Cognitive Science. - 2015. - V. 19, № 6. P. 339-348.

3. Paxton, A. Finding the Traces of Behavioral and Cognitive Processes in Big Data and Naturally Occurring Datasets / A. Paxton, T.L. Griffiths // Behavior Research Methods. - 2017. - V. 49, № 5. - P. 1630-1638.

4. Кубасов, И.А. Кластеризация объектов со слабо формализуемыми признаками на основе нейронной сети в виде слоя Кохонена / А.В. Мельников, С.А. Мальцев, И.Р. Нарушев // Вестник ВГУИТ. - 2018. - Т. 80, № 3. - С. 86-91. 
5. Нарушев, И.Р. Модели обобщенного показателя девиантного поведения несовершеннолетних / И.Р. Нарушев, А.В. Мельников, В.В. Денисенко // Вестник Воронежского института МВД России. - 2018. - № 1. - С. 44-50

6. Мельников, А.В. Обобщенный показатель девиантного поведения несовершеннолетних / А.В. Мельников, И.Р. Нарушев // Интеллектуальные информационные системы: труды Всероссийской конференции с международным участием. 2017. - C. 185-188.

7. Нарушев, И.Р. Численный метод сшивания объектовой базы экспертизы девиантного поведения несовершеннолетних при использовании метода анализа иерархий / И.Р. Нарушев, С.А. Мальцев, И.А. Кубасов // Вестник Воронежского института ФСИН России. - 2018. - № 4. - С. 89-97.

8. Саати, Т. Принятие решений. Метод анализа иерархий / Т. Саати. - М.: Радио и связь, 1993. - 320 с.

9. Саати, Т. Аналитическое планирование. Организация систем / T. Саати, К. Кернс. - М.: Радио и связь, 1991. - 224 с.

10. Саати, Т. Принятие решений при зависимостях и обратных связях: Аналитические сети / Т. Саати. - М.: Издательство ЛКИ, 2008. - 360 с.

Нарушев Илья Романович, адъюнкт института, кафедра математики и моделирования систем, Воронежский институт МВД России, (ә. Воронеж, Российская Федерачия),nar_i@bk.ru.

Мельников Александр Владимирович, доктор технических наук, профессор кафедры математики и моделирования систем, доцент, Воронежский институт МВД России (г. Воронеж, Российская Федераиия), теln78@таil.ru.

Кубасов Игорь Анатольевич, доктор технических наук, профессор кафедры информационных технологий, Академия управления МВД России, (г. Москва, Российская Федерачия), igorak@list.ru

Поступила в редакцию 7 июня 2019 г. 